\title{
PENGARUH STRATEGI PEMBELAJARAN DAN MOTIVASI BELAJAR TERHADAP KEMAMPUAN MEMBACA SISWA DALAM MATA PELAJARAN BAHASA JERMAN
}

\author{
Juwita \\ Guru SMK Negeri 17 Medan \\ juwita90@gmail.com
}

\begin{abstract}
Abstrak: Tujuan penelitian ini adalah untuk mengetahui: (1) kemampuan membaca bahasa Jerman siswa yang diajar dengan strategi pembelajaran kelompok lenih tinggi dibandingkan dengan siswa yang diajar dengan strategi pembejaran individual, (2) kemampuan membaca bahasa Jerman siswa yang memiliki motivasi belajar tinggi lebih tinggi dibandingkan dengan siswa yang memiliki motivasi belajar rendah, dan (3) interaksi antara strategi pembelajaran dan motivasi belajar terhadap kemampuan membaca bahasa Jerman. Populasi penelitian ini adalah 160 siswa dari 4 kelas X SMA N 17 Medan dan berdasarkan teknik cluster random sampling 80 siswa terpilih sebagai sampel. Instrumen penelitian untuk kemampuan membaca adalah 40 butir soal pilihan berganda dengan 5 pilihan jawaban dan untuk motivasi belajar digunakan angket motivasi belajar. Desain penelitian adalah faktorial $2 \times 2$ dan teknik analisis data adalah Analisis Varians (ANAVA) dua jalur pada taraf signifikansi $\alpha=0.05$. Hasil analisis data menunjukkan bahwa: (1) Kemampuan membaca siswa yang diajar dengan strategi pembelajaran kolaboratif lebih tinggi dibandingkan dengan hasil belajar Fisika siswa yang diajarkan dengan strategi pembelajaran individu, (2) kemampuan membaca siswa dengan motivasi belajar tinggi lebih tinggi dibandingkan dengan kemampuan membaca siswa dengan motivasi belajar rendah, dan (3) interaksi antara strategi pembelajaran dengan motivasi belajar dalam mempengaruhi kemampuan membaca.
\end{abstract}

Kata Kunci: strategi pembelajaran, motivasi belajar, kemampuan membaca, bahasa jerman.

Abstract: The objectives of research were to discover: (1) the students reading ability were taught in German language with group instructional strategy and individual instructional strategy, (2) the students reading ability who have high motivation learning than that having low motivationlearning, and (3) whether there was an interaction between learning strategy and motivation learning on students reading ability. The population of the study was 160 students from three classes Grade X State $17^{\text {th }}$ Senior High School Medan and based on cluster random sampling technique 80 students were chosen as the sample. The research instrument used to test the reading ability in German language was a 40 items multiple choice with five options and a test of motivation learning used questioner motivation learning. The design of the research was $2 \times 2$ factorial while and the technique of data analysis was a two-way Analysis of Variance (ANOVA) at the level of significance $\alpha=0.05$. The results of data analisysis showed that: (1) the students reading ability were taught in German language with group instructional strategy and individual instructional, (2) the students reading ability who have high motivation learning than that having low motivation learning, and (3) there was an interaction between learning strategy and motivation in affecting students reading ability in german language

Keywords: learning strategy, learning motivation, reading ability, german language.

\section{PENDAHULUAN}

Membaca merupakan sesuatu yang vital dalam suatu masyarakat terpelajar. Namun, anak-anak yang tidak memahami pentingnya belajar membaca tidak akan termotivasi untuk belajar. Di samping itu, kemampuan membaca merupakan tuntutan realitas kehidupan seharihari manusia. Beribu judul buku dan berjuta Koran diterbitkan setiap hari. Ledakan informasi ini menimbulkan tekanan pada guru untuk menyiapkan bacaan yang memuat informasi yang relevan untuk siswa-siswinya. Walaupun tidak semua informasi perlu dibaca, tetapi jenis-jenis bacaan tertentu yang sesuai dengan kebutuhan dan kepentingan kita tentu perlu dibaca.

Kemampuan membaca siswa dalam mata pelajaran Bahasa Jerman adalah berupa 
kemampuan yang dimiliki siswa yaitu mencakup kemampuan: (1). Memahami arti kata-kata dan istilah-istilah dalam suatu bacaan; (2) memahami makna kalimat yang terdapat dalam bacaan; (3) memahami gagasan pokok dan gagasan pendukung, termasuk kemampuan menyimpulkan isi bacaan setelah selesai proses pembelajaran (Nurhadi 1995). Hal ini dapat dilihat dari perubahan tingkah lakunya, seorang siswa mampu dan terampil mengidentifikasi, mengamati, memahami wacana, mencari hubungan, terampil berkomunikasi baik secara lisan maupun tulisan.

Ningsih (2007) tentang membaca adalah sebagai suatu proses mental atau proses kognitif yang di dalam proses tersebut seorang pembaca dapat mengikuti dan merespon pesan yang disampaikan oleh penulis. Dari keterangan tersebut dapat ditentukan bahwa kegiatan membaca merupakan sebuah kegiatan yang bersifat aktif dan interaktif. Dengan pengetahuannya, pembaca berusaha mengikuti jalan pikiran penulis dengan daya kritisnya pembaca ditantang untuk dapat merespon dengan menyetujui atau tidak menyetujui gagasan atau ide - ide

yang dikemukakan oleh seseorang melalui tulisannya. Kebanyakan peserta didik tidak memiliki hasrat untuk membaca teks atau bacaan berbahasa asing karena mereka menggangap terlalu sulit untuk memahaminya dan tidaklah mengherankan jika mereka memiliki motivasi yang sangat rendah. Peranan guru untuk menggugah motivasi peserta didik dalam membaca bacaan bahasa asing sangatlah dibutuhkan dengan member masukan pada peserta didik untuk berlatih memahami makna dari bacaan berbahasa asing yang dibacanya. Abdurahman (2003) membaca merupakan aktifitas kompleks yang mencakup fisik dan mental. Aktifitas fisik tang terkait dengan membaca adalah gerakan mata dan ketajaman penglihatan. Aktifitas mental mencakup ingatan dan pemahaman.

Tujuan membaca adalah menemukan informasi dan mendapatkan kesenangan,maka seorang pembaca harus memulai kegiatannya dengan perasaan senang dan keinginannya tinggi. Halim (1976) mengatakan bahwa membaca bukan sekedar melisankan kata-kata tertulis dan bukan hanya menangkap sebuah makna yang sudah pasti ada dalam tuturan tulisan. Lebih dari itu membaca merupakan suatu proses mental yang melibatkan kemampuan berpikir, pengetahuan dan pengalaman membaca secara aktif dan kreatif untuk memahami serta member makna apa yang telah dibaca. Membaca adalah suatu kegiatan reseptif dan produktif. Membaca adalah kegiatan yang kompleks, mulai dari memahami bahasa tulisan (ejaan, tanda baca), memahami arti kata-kata, kalimat sampai memahami isi bacaan.

Menurut Kartono (1995) menyatakan perbedaan kemampuan seseorang dalam memahami isi bacaan dipengaruhi oleh factor internal dan eksternal. Faktor internal yang mempengaruhi kemampuan siswa dalam memahami isi bacaan adalah intelegensi, minat, motivasi dan teknik membaca, sedangkan faktor eksternal misalnya penggunaan kalimat atau kata-kata yang tidak teratur, adanya istilahistilah baru yang belum diketahui dalam bacaan.

Teknik pengajaran membaca sangat kuat mempengaruhi motivasi membaca seorang siswa yang pada gilirannya juga akan mempengaruhi tingkat kemampuan membaca yang menjadi tujuan utama dari membaca itu sendiri. Seorang siswa diharapkan mendapat informasi dari bacaan tersebut, selain itu juga diharapkan seorang siswa mampu meringkas teks yang dibaca.

Pada SMA Negeri 17 Kecamatan Medan Tuntungan, mata pelajaran bahasa Jerman telah diberikan sejak para siswa duduk di bangku kelas 1 SMA. Walaupun menjadi mata pelajaran baru yang mungkin terasa asing bagi siswa karena belum pernah terdengar pada tingkatan sekolah sebelumnya, namun para siswa dituntut untuk dapat menguasai Bahasa Jerman layaknya seperti mata pelajaran lainnya.

Guna meningkatkan proses belajar mengajar Bahasa Jerman di SMA Negeri 17 Medan, selain gurunya yang cukup memadai (terdapat 2 orang) pada umumnya telah banyak dilakukan aktivitas pembelajaran yang menunjang pemahaman dan peningkatan penguasaan Bahasa Jerman seperti latihan membaca, latihan menulis, menjawab soal-soal dari buku paket, mendengar Bahasa Jerman melalui tape recorder dan mengucapkan Bahasa Jerman dengan benar, namun belum banyak menunjukkan peningkatan menguasai Bahasa Jerman yang maksimal atau seperti yang diharapkan. Nilai ujian yang didapatkan dari kelas satu hingga kelas tiga masih menunjukkan rata-rata kurang memuaskan.

Menurut Skinner (1953) masalah belajar terjadi karena subyek (siswa) tidak 
memiliki respon yang siap, yang akan mengurangi keterbelakangan karena adanya masalah belajar. Ibarat suatu kamar yang terlalu panas, terjadi masalah jika kita tidak bisa membuka jendelanya. Masalah itu dipecahkan jika kita bisa membuka jendelanya. Masalah belajar bisa dipecahkan jika guru dapat mengubah situasi, sehingga respons yang sudah tersedia dapat terjadi. Kita menemukan caracara baru agar jendelanya terbuka sehingga ruangan menjadi sejuk.

Beberapa penelitian yang dilakukan oleh para ahli bahwa rendahnya hasil belajar siswa disebabkan beberapa hal seperti dikemukakan oleh Hasibuan (2006) bahwa "Dalam proses belajar selalu terdapat perbedaan individu antara siswa yang satu dengan siswa yang lain dalam kelas". Pengajaran secara klasikal yang dianggap efisien belum tentu dapat mencapai target penguasaan bagi semua siswa, karena tingkat pencapaian penguasaan bahan/materi pelajaran antara siswa yang satu dengan siswa yang lain sangat bervariasi.

Dick dan Carey (2005) menyatakan bahwa strategi pembelajaran merupakan komponen-komponen umum dari suatu bahan pembelajaran dan prosedur-prosedur yang akan dugunakan untuk menghasilkan hasil belajar tertentu pada siswa. Suparman (1997) juga mengemukakan bahwa strategi pembelajaran dalam mengelola kegiatan pembelajaran untuk menyampaikan materi secara sistematik sehingga kemampuan yang diharapkan dapat dikuasai oleh pembelajaran secara efektif dan efisien.

Berdasarkan hal di atas yang dimaksud dengan strategi pembelajaran adalah cara yang sistematis dan baik untuk menciptakan interaksi siswa dengan lingkungannya agar menghasilkan tingkat pengembangan diri dalam belajar. Penggunaan suatu strategi pembelajaran untuk segala tujuan belajar tidak akan selalu efektif (Nasution 1982). Setiap strategi mempunyai batas-batas kebaikan dan kelemahan, bukan saja terhadap tujuan tertentu tetapi juga terhadap situasi tertentu. Jadi semua strategi dapat digunakan untuk meningkatkan kemampuan siswa, guru dituntut untuk dapat memilih dan menggunakan strategi yang sesuai dengan tingkat motivasi siswa, mata pelajaran yang diajarkan, latar belakang siswa, lingkungan siswa maupun usia siswa.

Strategi pembelajaran kelompok adalah cara mengajar guru dalam kelas dengan membagi siswa menjadi beberapa kelompok.
Menurut Winkel (1991:90) tentang teori pembelajaran kooperatif bahwa pembelajaran kelompok dianggap sebagai cara belajar yang sangat baik. Pengelompokan siswa dalam belajar sudah diuraikan pada pembahasan pembelajaran individual yaitu disebabkan perbedaan motivasi belajar dan menurut taraf kemampuan belajar siswa. Proses pembelajaran di kelas berlangsung dalam interaksi dan komunikasi antar para siswa dan guru, tetapi juga dalam kontak antar siswa yang satu dengan yang lain. Melalui komunikasi antar siswa ini dapat menghubungkan apa yang sudah dipahaminya dan dilakukannya dengan apa yang akan diajarkan kepadanya. Yang mengajarkan sesuatu bukan selalu guru secara langsung melainkan dapat juga antar siswa, meskipun mendapat pengawasan dari guru, misalnya untuk memahami suatu isi bacaan yang dianggap sulit, perlu pemecahan secara bersama-sama yaitu dengan membentuk kelompok belajar.

Sujarwo (1988) mengatakan bahwa strategi pembelajaran kelompok pada umumnya bermaksud untuk merangsang efektivitas interaktif kelompok belajar, maka hal ini jelas diperlukan kelompok dalam ukuran yang sesuai dengan situasi khusus masing-masing. Bentuk atau ukuran optimal kelompok tergantung kepada berbagai factor, termasuk tujuan dan sifat latihan dan berbagai hambatan yang terjadi karena logistik yang diperlukan datang terlambat. Misalnya pendidikan simulasi dan permainan perlu jumlah partisipasi yang relatif khusus terutama apabila hal itu diatur secara rapi. Sebagai patokan umum setiap kelompok belajar sebaiknya beranggotakan tidak lebih dari 10 siswa. Dengan jumlah sebesar itu diharapkan efektifitas peningkatan interaksi kelompok dan pengembangan keterampilan kelompok dapat dicapai. Jumlah yang ideal untuk satu kelompok sebaiknya berkisar antara 4 sampai 6 siswa.

Pembelajaran individual merupakan suatu upaya untuk memberikan kesempatan kepada siswa agar dapat belajar sesuai dengan kebutuhan, kemampuan, kecepatan dan caranya sendiri. Skinner (1989) mengatakan bahwa belajar adalah perubahan tingkah laku. Analisa eksperimen Skinner menuntut studi terhadap subyek secara perseorangan bukan secara kelompok. Skinner dianggap sebagai perintis pembelajaran individual. Penerapan strategi ini menurut Skinner mengingat ciri sibelajar di dalam kelas mempunyai perbedaan 
perseorangan dalam hal tingkah laku yang dibawanya ke dalam situasi belajar dan berpengaruh pada perolehan tingkah laku yang baru. Dalam teori psikologi perilaku yang dikemukakannya bertujuan mencoba untuk menemukan bagaimana peranan belajar dalam memajukan situasi belajar yang terbaik sesuai dengan karakteristik yang dimiliki siswa.

Sujana dan Rivai (2001) mengatakan bahwa tujuan utama pembelajaran individual ialah agar para siswa dapat belajar secara optimal serta bias mencapai tingkat penguasaan bahan pelajaran yang dipelajarinya, misalnya guru memberi teks bacaan agar siswa membacanya secara individual untuk memahami isinya. Berbagai bentuk pembelajaran yang diindualisasikan itu semuanya menekankan pentingnya perhatian, bantuan dan perlakuan khusus kepada siswa, secara individual yang berbeda minat, kemampuan, bantuan, serta kecepatan belajarnya. Perbedaan individual dapat kita lihat antara lain: perkembangan intelektual, kemampuan berbahasa, latar belakang pengalaman, gaya belajar, bakat dan minat, serta kepribadian. Karena adanya perbedaan ini maka perlu strategi pembelajaran yang di individualisasikan. Pengolahannya memang tidak mudah. Untuk menyusun program individual diperlukan tujuan, bahan, dan kegiatan belajar yang berlainan. Guru harus mengontrol kegiatan siswa yang berbeda-beda, memerlukan waktu dan tenaga. Sekalipun demikian pembelajaran ini dapat dilaksanakan sebagian saja kalau bentuknya yang utuh tidak memungkinkan.

Motivasi adalah faktor kunci dalam belajar membaca. Eanes (1997) mengemukakan bahwa kunci motivasi itu sederhana, tetapi tidak mudah untuk mencapainya. Kuncinya adalah guru harus mendemontrasikan kepada siswa praktik pengajaran yang relevan dengan minat dan pengalaman dengan anak memahami belajar itu sebagai suatu kebutuhan. Menurut Sardiman (2003) motivasi berasal dari kata motif yang artinya sebagai daya upaya yang mendorong seseorang melakukan sesuatu. Motif dapat dikatakan sebagai pengerak dari dalam,dan didalam subjek untuk melakukan aktifitas tertentu demi mencapai tujuan. Berawal dari kata motif, maka motivasi diartikan sebagai daya pengerak yang telah menjadi aktif.

Motivasi siswa yang rendah diduga berpengaruh terhadap rendahnya hasil belajar siswa, karena siswa yang bermotivasi tinggi dan bermotivasi rendah diberikan metode pembelajaran yang sama, tentu hasilnya akan jauh berbeda.

Sehubungan dengan tingkat kebutuhan manusia, Luthans (1995) mengemukakan bahwa proses munculnya motivasi dimulai dengan Pidarta (1997) mengatakan bahwa faktor-faktor yang menentukan motivasi adalah: (1) minat dan kebutuhan individu. Bila minat dan kebutuhan jasmani, rohani dan social siswa dipenuhi, maka motivasi belajar akan muncul; (2) persepsi kesulitan akan tugas-tugas. Bila siswa memandang kesulitan pelajaran itu tidak terlalu berat, melainkan cukup menantang, maka motivasi belajar mereka pun akan muncul. Guru perlu mengoreksi materi pelajaran setiap kali akan mengajar agar kesulitan-kesulitan tidak menguras pikiran siswa-siswa; (3) harapan sukses. Harapan ini muncul karena siswa itu sering sukses. Agar siswa yang bodoh punya kesempatan seperti ini sebaiknya materi pelajaran dibuat bertingkat dan model evaluasi bersifat individual. Dengan cara ini semua siswa dalam kelas akan mempunyai motivasi yang positif untuk belajar.

Rumusan masalah pada penelitian ini adalah: (1) Apakah kemampuan membaca Bahasa Jerman siswa yang diajar dengan strategi pembelajaran kelompok lebih tinggi di bandingkan dengan yang diajar strategi pembelajaran individual?, (2) Apakah kemampuan membaca Bahasa Jerman siswa yang memiliki motivasi belajar tinggi lebih tinggi dibandingkan siswa yang memiliki motivasi belajar rendah?, (3) Apakah terdapat interaksi antara strategi pembelajaran dengan motivasi belajar dalam mempengaruhi kemampuan membaca Bahasa Jerman siswa?

\section{METODE}

Penelitian ini dilaksanakan di Sekolah Menengah Atas Negeri 17 Medan. Populasi atau universe adalah jumlah keseluruhan dari unit analisa yang ciri-cirinya akan diduga. Maka yang menjadi populasi dalam penelitian ini adalah kelas X SMA Negeri 17 Kecamatan Medan Tuntungan pada semester II yang terbagi atas empat kelas yaitu XA, XB, XC dan $\mathrm{XD}$ yang berjumlah 160 orang siswa.

Sampel penelitian diambil dengan teknik cluster sampling yaitu kelas XB dan XD berjumlah 80 orang. Kemudian setiap kelompok sampel dibagi dua yaitu kelas dengan perlakuan strategi pembelajaran kelompok dan kelas 
dengan perlakuan strategi pembelajaran individual. Pembagian setiap kelompok dilakukan secara acak. Pengacakan pada tahap ini dilakukan 2 kali sesuai tingkat motivasi belajar yang dimiliki sampel. Pengacakan pertama dilakukan kepada kelompok sampel yang memiliki tingkat motivasi belajar tinggi dan rendah, dan pengacakan kedua dilakukan kepada kelompok sampel untuk menentukan perlakuan yang akan diberikan. Dengan demikian diharapkan bahwa masing-masing kelompok yang mendapatkan perlakuan telah menggambarkan karakteristik sampel yang memiliki tingkat motivasi belajar tinggi maupun tingkat motivasi belajar rendah.

Penelitian ini menggunakan metode quasi experiment (eksperimen semu). Hal ini dimaksudkan karena di dalam eksperimen, kelas ini sudah terbentuk sebelumnya. Rancangan penelitian ini menggunakan desain faktorial $2 \times 2$ seperti digambarkan pada tabel 2 .

Tabel 2. Desain Penelitian Rancangan Eksperimen Factorial (2x2)

\begin{tabular}{|l|c|c|}
\hline \multirow{2}{*}{$\begin{array}{l}\text { Motivasi } \\
\text { belajar }\end{array}$} & \multicolumn{2}{|c|}{ Perlakuan } \\
\cline { 2 - 3 } & Kelompok (K) & Individual (I) \\
\hline Tinggi (T) & T K & T I \\
\hline Rendah (R) & R K & R I \\
\hline
\end{tabular}

Teknik pengumpulan data dalam penelitian ini menggunakan teknik tes dan non tes. Teknik tes dilakukan untuk mengumpulkan data tentang hasil belajar Bahasa Jerman. Sedangkan teknik non tes yang dalam penelitian ini menggunakan angket untuk mengumpulkan data tentang motivasi siswa. Tes hasil belajar berupa pertanyaan-pertanyaan dalam bentuk pilihan berganda dengan empat pilihan jawaban pada mata pelajaran Bahasa Jerman kelas X.

Teknik analisis data yang digunakan adalah teknik statistik deskriptif dan inferensial. Teknik statistik deskriptif digunakan untuk mendeskripsikan data antara lain mean, median, standard deviasi dan kecenderungan data. Teknik statistik inferensial digunakan untuk menguji hipotesis penelitian, dimana teknik inferensial yang digunakan adalah teknik analisis varians (ANAVA) dua jalur dengan taraf signifikan $0,05 \%$. Sebelum teknik analisis ini digunakan maka terlebih dahulu dilakukan uji persyaratan analisis, dilakukan dengan uji normalitas menggunakan uji Liliefors dan uji homogenitas menggunakan uji Bartlett (Sudjana, 2005: 261). Jika ada interaksi antar variabel, maka analisis dilanjutkan uji beda dengan menggunakan Uji Scheffe.

Berdasarkan hipotesis penelitian yang telah dirumuskan di muka, maka berikut ini dapat disusun hipotesis statistik yang akan diuji sebagai berikut:

1. Hipotesis Pertama

$$
\begin{aligned}
& H o: \mu_{A 1}=\mu_{A 2} \\
& H a: \mu_{A 1}>\mu_{A 2}
\end{aligned}
$$

2. Hipotesis Kedua

$$
\text { Ho }: \mu_{B 1}=\mu_{B 2}
$$$$
H a: \mu_{B 1}>\mu_{B 2}
$$

3. Hipotesis Ketiga

$$
\begin{aligned}
& H o: A \times B=0 \\
& H a: A \times B \neq 0
\end{aligned}
$$

\section{HASIL PENELITIAN}

\begin{tabular}{|c|c|c|c|}
\hline \multirow{2}{*}{$\begin{array}{c}\text { Motivasi Belajar } \\
\text { (B) }\end{array}$} & \multicolumn{2}{|c|}{ Strategi Pembelajaran (A) } & \multirow[b]{2}{*}{ Total } \\
\hline & $\begin{array}{c}\text { Kelompok } \\
\left(A_{1}\right)\end{array}$ & $\begin{array}{c}\text { Individu } \\
\left(\mathbf{A}_{2}\right)\end{array}$ & \\
\hline Tinggi (B) & $\begin{array}{l}\mathrm{n}_{\mathrm{A} 1 \mathrm{~B} 1}=21 \\
\bar{X} \mathrm{~A} 1 \mathrm{~B} 1=28,81 \\
\mathrm{SD}=4,50 \\
\Sigma X=1025\end{array}$ & $\begin{array}{l}\mathrm{n}_{\mathrm{A} 2 \mathrm{~B} 1}=20 \\
\bar{X} \quad \mathrm{~A} 2 \mathrm{~B} 1=25,25 \\
\mathrm{SD}=3,58 \\
\Sigma X=505\end{array}$ & $\begin{array}{l}\mathrm{n}_{\mathrm{tbd}}=41 \\
\bar{X}_{\mathrm{tb}}=27,07 \\
\mathrm{SD}=4,41 \\
\Sigma X=1091\end{array}$ \\
\hline
\end{tabular}

Rangkuman data tersebut dapat dilihat pada Tabel 3 dengan menggunakan analisis deskriptif.

Tabel 3. Data Kemampuan Membaca Bahasa Jerman Siswa. 


\begin{tabular}{|c|l|l|l|} 
& $\Sigma X^{2}=17835$ & $\Sigma X^{2}=12995$ & $\Sigma X^{2}=30469$ \\
\hline \multirow{4}{*}{ Rendah $\left(\mathbf{B}_{2}\right)$} & $\mathrm{n}_{\mathrm{A} 1 \mathrm{~B} 2}=19$ & $\mathrm{n}_{\mathrm{A} 2 \mathrm{~B} 2}=20$ & $\mathrm{n}_{\mathrm{tbk}}=39$ \\
& $\bar{X}$ A1B2 $=25,95$ & $\bar{X}{ }_{\mathrm{A} 2 \mathrm{~B} 2}=26$ & $\bar{X}$ tb $=25,97$ \\
& $\mathrm{SD}=4,35$ & $\mathrm{SD}=3,92$ & $\mathrm{SD}=408$ \\
& $\Sigma X=657$ & $\Sigma X=520$ & $\Sigma X=1013$ \\
& $\Sigma X^{2}=13133$ & $\Sigma X^{2}=13812$ & $\Sigma X^{2}=26945$ \\
\hline \multirow{5}{*}{ Total } & $\mathrm{n}_{\mathrm{tkk}}=40$ & $\mathrm{n}_{\mathrm{tki}}=40$ & $\mathrm{n}_{\mathrm{tot}}=80$ \\
& $\bar{X}$ A1B1 $=27,45$ & $\bar{X} \mathrm{~A} 1 \mathrm{~B} 1=25,63$ & $\bar{X}$ tot $=26,50$ \\
& $\mathrm{SD}=4,61$ & $\mathrm{SD}=3,73$ & $\mathrm{SD}=4,09$ \\
& $\Sigma X=1098$ & $\Sigma X=1025$ & $\Sigma X=2123$ \\
& $\Sigma X^{2}=30968$ & $\Sigma X^{2}=26807$ & $\Sigma X^{2}=57414$ \\
\hline
\end{tabular}

Hasil perhitungan ANAVA seperti yang ditunjukkan dalam tabel 3, yaitu rangkuman analisis faktorial $2 \times 2$. seperti ditunjukkan pada tabel 4 .

Tabel 4. Rangkuman Analisis Faktorial 2x2

\begin{tabular}{|l|r|c|r|r|r|l|}
\hline \multicolumn{1}{|c|}{$\begin{array}{c}\text { Sumber } \\
\text { Varians }\end{array}$} & \multicolumn{1}{c|}{ JK } & dk & RJK & F $_{\text {hitung }}$ & $\mathbf{F}_{\text {tabel }}$ & Kesimpulan \\
\hline Strategi & 66,61 & 1 & 66,61 & 3,99 & 3,96 & signifikan \\
Pembelajaran & 995,84 & 1 & 995,84 & 59,04 & 3,96 & $\begin{array}{l}\text { signifikan } \\
\text { signifikan }\end{array}$ \\
Motivasi Belajar & 908,50 & 1 & 908,50 & 53,86 & 3,96 & \\
Interaksi & 153,95 & 3 & & - & & \\
\hline Antar kelompok & 1281,94 & 76 & 16,87 & & & \\
Dalam kelompok & 1435,89 & 79 & & & & \\
\hline Total & 1439 & & & \\
\hline
\end{tabular}

\section{Hipotesis Pertama.}

Pengujian hipotesis pertama yang menyatakan: kemampuan membaca bahasa Jerman siswa yang dibelajarkan dengan strategi pembelajaran kelompok lebih tinggi daripada kemampuan membaca siswa yang diajarkan dengan strategi pembelajaran individu.

Hipotesis statistiknya adalah:

$$
\begin{aligned}
& \text { Ho }: \mu S_{\text {pKel }}=\mu S_{\text {pInd }} \\
& \text { Ha }: \mu S_{\text {pKel }}>\mu S_{\text {pInd }} \\
& \text { Berdasarkan perhitungan ANAVA }
\end{aligned}
$$
faktorial $2 \times 2$ diperoleh $\mathrm{F}_{\text {hitung }}=3,99$ sedangkan nilai $\mathrm{F}_{\text {tabel }}=3,96$ untuk dk $(1,76)$ dan taraf nyata $\alpha=0,05$. Ternyata nilai $F_{\text {hitung }}=3,99>F_{\text {tabel }}$ sehingga pengujian hipotesis menolak Ho dan menerima Ha. Dengan demikian dapat ditarik kesimpulan bahwa kemampuan membaca bahasa Jerman siswa yang dibelajarkan dengan strategi pembelajaran kelompom lebih tinggi dibanding dengan strategi individu dapat diterima dan terbukti secara empirik. Hal ini juga terlihat dari rata-rata kemampuan membaca bahasa Jerman yang dibelajarkan dengan strategi kelompok $(\bar{X}=27,5)$ lebih tinggi dari kemampuan membaca bahasa Jerman yang dibelajarkan dengan strategi individu $(\bar{X}=25,55)$.

\section{Hipotesis Kedua}

Pengujian hipotesis yang kedua yaitu kemampuan membaca siswa dengan Motivasi tinggi lebih tinggi daripada hasil belajar siswa dengan motivasi rendah.

Hipotesis statistiknya adalah:

Ho : $\mu \mathrm{M}_{\mathrm{T}} \leq \mu \mathrm{M}_{\mathrm{R}}$

$\mathrm{Ha}: \mu \mathrm{M}_{\mathrm{T}}>\mu \mathrm{M}_{\mathrm{R}}$

Berdasarkan perhitungan ANAVA faktorial $2 \times 2$ diperoleh $\mathrm{F}_{\text {hitung }}=59,04$ sedangkan nilai $\mathrm{F}_{\text {tabel }}=3,96$ untuk dk $(1,76)$ dan taraf nyata $\alpha=0,05$. Ternyata nilai $F_{\text {hitung }}=59,04>F_{\text {tabel }}$ sehingga pengujian hipotesis menolak Ho dan menerima Ha. Dengan demikian dapat ditarik kesimpulan bahwa kemampuan membaca bahasa Jerman siswa dengan motivasi tinggi lebih tinggi daripada kemampuan membaca bahasa Jerman siswa dengan motivasi rendah dapat diterima dan terbukti secara empirik. Hal ini juga terlihat dari rata-rata kemampuan membaca bahasa Jerman siswa dengan motivasi 
tinggi $(\bar{X}=27,07)$ lebih tinggi dari kemampuan membaca bahasa Jerman siswa dengan motivasi belajar rendah $(\bar{X}=25,97)$.

\section{Hipotesis Ketiga}

Pengujian hipotesis yang ketiga yaitu: terdapat interaksi antara strategi pembelajaran dan motivasi belajar dalam meningkatkan hasil belajar bahasa Jerman.

Hipotesis statistiknya adalah:

$$
\begin{aligned}
& \text { Ho: } S_{p} X M_{b}=0 \\
& \text { Ha }: S_{p} X M_{b} \neq 0 \\
& \text { Berdasarkan perhitungan ANAVA }
\end{aligned}
$$

faktorial $2 \times 2$ diperoleh $\mathrm{F}_{\text {hitung }}=53,86$ sedangkan nilai $\mathrm{F}_{\text {tabel }}=3,96$ untuk $\mathrm{dk}(1,76)$ dan taraf nyata $\alpha=0,05$. Ternyata nilai $F_{\text {hitung }}=53,86>F_{\text {tabel }}$ sehingga pengujian hipotesis menolak Ho. Dengan demikian dapat ditarik kesimpulan bahwa terdapat interaksi antara strategi pembelajaran dan motivasi belajar dalam meningkatkan kemampuan membaca bahasa Jerman siswa dapat diterima dan terbukti secara empirik.

Untuk mengetahui interaksi antara strategi pembelajaran dan motivasi belajar terhadap kemampuan membaca bahasa Jerman, maka dilakukan uji lanjut dengan Uji Scheffe. Ditunjukkan pada tabel 5 sebagai berikut:

Tabel 5. Rangkuman Hasil Uji Scheffe

\begin{tabular}{|l|l|c|c|}
\hline \multicolumn{2}{|c|}{ Hipotesis Statistik } & $F_{\text {hitung }}$ & $\begin{array}{c}F_{\text {tabel }}(3,76) \\
\alpha=0,05\end{array}$ \\
\hline Ho: $\mu_{\mathrm{A} 1 \mathrm{~B} 2}=\mu_{\mathrm{A} 1 \mathrm{~B} 1}$ & Ha: $\mu_{\mathrm{A} 1 \mathrm{~B} 1}<\mu_{\mathrm{A} 1 \mathrm{~B} 2}$ & 1,69 & 2,72 \\
\hline Ho: $\mu_{\mathrm{A} 2 \mathrm{~B} 1}=\mu_{\mathrm{A} 1 \mathrm{~B} 1}$ & Ha: $\mu_{\mathrm{A} 2 \mathrm{~B} 1}<\mu_{\mathrm{A} 1 \mathrm{~B} 1}$ & 2,16 & 2,72 \\
\hline Ho: $\mu_{\mathrm{A} 1 \mathrm{~B} 1}=\mu_{\mathrm{A} 2 \mathrm{~B} 2}$ & Ha: $\mu_{\mathrm{A} 1 \mathrm{~B} 1}<\mu_{\mathrm{A} 2 \mathrm{~B} 2}$ & 1,71 & 2,72 \\
\hline Ho: $\mu_{\mathrm{A} 1 \mathrm{~B} 2}=\mu_{\mathrm{A} 2 \mathrm{~B} 1}$ & Ha: $\mu_{\mathrm{A} 1 \mathrm{~B} 2}<\mu_{\mathrm{A} 2 \mathrm{~B} 1}$ & 0,40 & 2,72 \\
\hline Ho: $\mu_{\mathrm{A} 1 \mathrm{~B} 2}=\mu_{\mathrm{A} 2 \mathrm{~B} 2}$ & Ha: $\mu_{\mathrm{A} 1 \mathrm{~B} 2}<\mu_{\mathrm{A} 2 \mathrm{~B} 2}$ & 0,03 & 2,72 \\
\hline Ho: $\mu_{\mathrm{A} 2 \mathrm{~B} 1}=\mu_{\mathrm{A} 2 \mathrm{~B} 2}$ & Ha: $\mu_{\mathrm{A} 2 \mathrm{~B} 1}<\mu_{\mathrm{A} 2 \mathrm{~B} 2}$ & 0,44 & 2,72 \\
\hline
\end{tabular}

Hasil pengujian lanjut, menunjukkan adanya interaksi antara strategi pembelajaran dan gaya berpikir terhadap kemampuan membaca bahasa Jerman siswa SMA Negeri 17
Medan. Interaksi strategi pembelajaran dan motivasi belajar dapat ditunjukkan seperti pada Gambar 1 berikut ini.

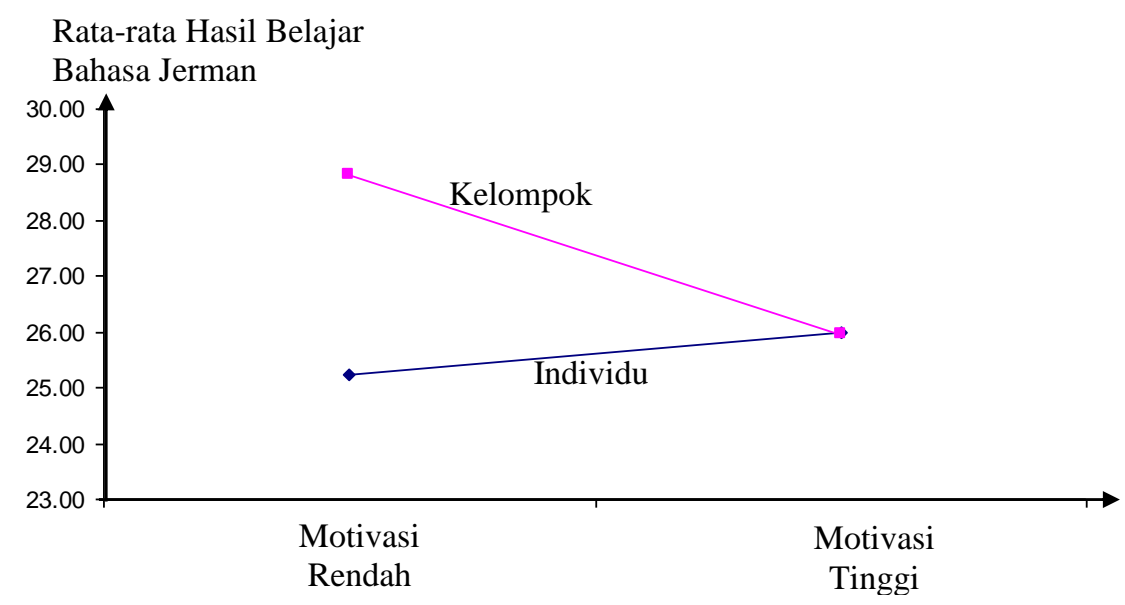

Gambar 1. Interaksi antara Strategi Pembelajaran dan Motivasi Belajar

\section{PEMBAHASAN
Berdasarka}

uraian sebelumnya

keseluruhan rata-rata kemampuan membaca bahasa Jerman siswa SMA Negeri 17 Medan yang dibelajarkan 
dengan strategi pembelajaran kelompok $(\bar{X}=$ $27,45)$ lebih baik daripada rata-rata hasil belajar bahasa Jerman siswa yang dibelajarkan dengan strategi pembelajaran kompetitif $(\bar{X}=25,62)$. Hal ini menunjukkan bahwa strategi pembelajaran kelompok terbukti efektif dapat meningkatkan hasil belajar bahasa Jerman secara keseluruhan baik untuk kelompok motivasi belajar tinggi maupun motivasi belajar rendah. Dengan demikian hipotesis pertama yang peneliti ajukan yaitu kemampuan membaca Bahasa Jerman siswa yang dibelajarkan dengan strategi pembelajaran kelompok lebih tinggi daripada hasil belajar siswa yang diajarkan dengan strategi pembelajaran individu dapatlah diterima.

Seperti yang telah diungkapkan Davis (1993) bahwa ciri utama dari pembelajaran kelompok adalah: (1) siswa bekerja dalam tim untuk menguasai materi pelajaran, (2) tim atau kelompok dibentuk bervariasi dari siswa yang memiliki kinerja akademis tinggi, sedang dan rendah, (3) tim terdiri dari anggota yang bervariasi dari segi jenis kelamin dan ras dan (4) sistem ganjaran berorientasi pada kelompok, bukan individu. Sebaliknya strategi individu merupakan suatu jenis strategi pembelajaran yang para siswanya belajar dan menyelesaikan tugas-tugasnya secara individual atau mandiri. Jenis pembelajaran ini sebenarnya merupakan jenis pembelajaran yang dilakukan oleh guru selama ini. Latar pembelajarannya adalah kelas dan para siswa diberi arahan, penjelasan dan penugasan oleh guru kemudian mereka mengerjakannya secara sendiri-sendiri tanpa ada interaksi langsung dari teman-teman sekelasnya.

Secara psikologis pembelajaran individu berlangsung di dalam kelas merupakan refleksi dari prinsip individualitas. Rohani dan Ahmadi (1995) menjelaskan prinsip individualitas dalam konteks pembelajaran sebagai berikut: (1) setiap individu mempunyai sifat-sifat, bakat dan kemampuan yang berbeda, (2) setiap individu mempunyai cara belajar menurut caranya sendiri, (3) setiap individu mempunyai minat khusus yang berbeda, (4) setiap individu membutuhkan bimbingan khusus dalam menerima pelajaran yang diajarkan guru sesuai dengan perbedaan individual dan (5) setiap individu mempunyai irama pertumbuhan dan perkembangan yang berbeda-beda.
Hipotesis pertama yang menyatakan kemampuan membaca siswa yang dibelajarkan dengan strategi pembelajaran kelompok lebih tinggi daripada kemampuan membaca siswa yang dibelajarkan dengan strategi pembelajaran individu. Hal ini dapat dimaklumi karena melalui strategi pembelajaran kelompok dapat mendorong siswa untuk aktif belajar karena siswa dapat saling berdiskusi, bekerjasama, bertukar pendapat dalam mempelajari materi ajar. Di samping itu strategi pembelajaran kelompok bertujuan menumbuhkan partisipasi siswa dalam memecahkan isu atau masalah yang diajukan oleh guru dalam pembelajaran, menumbuhkan diskusi di antara siswa dalam mencari penyebab dan solusi terhadap isu atau masalah tersebut.

Oleh karena itu peran guru dalam pembelajaran kelompok sebagai fasilitator yang mengarahkan siswa untuk menemukan dan mengkonstruk sendiri pengetahuannya.

Dari hasil analisis data secara keseluruhan diperoleh rata-rata kemampuan membaca siswa dengan motivasi belajar tinggi lebih tinggi dari kemampuan membaca siswa dengan motivasi belajar rendah. Hal ini berindikasi bahwa siswa yang dengan motivasi belajar tinggi secara rata-rata mempunyai kemampuan membaca bahasa Jerman yang lebih tinggi dibanding siswa dengan motivasi belajar rendah. Dengan demikian siswa dengan motivasi belajar tinggi lebih memahami dan menguasai materi pelajaran bahasa Jerman dibandingkan siswa dengan motivasi belajar rendah.

Dengan demikian dapat disimpulkan bahwa siswa yang motivasi belajar tinggi dalam menyelesaikan masalah mempunyai karakteristik: (1) menganalisis masalah ke dalam komponen yang lebih rinci, (2) mengeliminasi berbagai alternatif penyelesaian secara rasional dan (3) sistematis.

Berdasarkan pemaparan di atas dapat dipahami bahwa kemampuan membaca bahasa Jerman siswa dengan motivasi belajar tinggi lebih tinggi dibandingkan dengan kemampuan membaca bahasa Jerman siswa dengan motivasi belajar rendah.

Apabila dilihat dari rata-rata nilai hasil belajar bahasa Jerman kelompok siswa dengan motivasi belajar tinggi dan diajar dengan strategi pembelajaran individu lebih tinggi dibandingkan dengan rata-rata kemampuan membaca bahasa Jerman kelompok siswa dengan motivasi belajar tinggi dan diajar 
dengan strategi pembelajaran kelompok. Kemudian rata-rata hasil belajar bahasa Jerman kelompok siswa dengan motivasi belajar rendah dan diajar dengan strategi individu lebih rendah dibandingkan dengan rata-rata hasil belajar kemampuan membaca bahasa Jerman kelompok siswa dengan motivasi belajar rendah dan diajar dengan strategi kelompok.

Hal ini bermakna bahwa bagi kelompok siswa dengan motivasi belajar tinggi lebih baik menggunakan strategi pembelajaran kelompok dibandingkan dengan strategi pembelajaran individu, walaupun perbedaannya tidak terlalu signifikan. Pembelajaran kelompok dapat menyediakan peluang untuk menuju pada kesuksesan praktek-praktek pembelajaran. Sebagai teknologi untuk pembelajaran (technology for instruction), pembelajaran kelompok melibatkan partisipasi aktif para siswa dan meminimisasi perbedaan-perbedaan antar individu. Berdasarkan pemaparan di atas dapat dipahami bahwa siswa dengan motivasi belajar tinggi akan memperoleh kemampuan membaca bahasa Jerman yang lebih tinggi jika diajar dengan strategi pembelajaran kelompok, sedangkan siswa dengan motivasi belajar rendah akan memperoleh kemampuan membaca bahasa Jerman yang lebih tinggi jika diajar dengan strategi pembelajaran individu. Oleh karena itu dapat dipahami bahwa terdapat interaksi antara strategi pembelajaran dan motivasi belajar dalam mempengaruhi kemampuan membaca bahasa Jerman siswa.

Pelaksanaan penelitian ini telah diusahakan dengan sebaik dan sesempurna mungkin dengan menggunakan prosedur metode ilmiah, akan tetapi tidak menutup kemungkinan terdapatnya keterbatasanketerbatasan.

Pertama, ketika menjaring data motivasi dengan menggunakan angket yang diberikan kepada siswa, maka dalam pelaksanaanya diduga terdapat siswa memberikan pilihan atas option pernyataan angket tidak sesuai dengan keadaan sebenarnya. Untuk mengatasi hal tersebut maka dalam pelaksanaan pemberian angket diperlukan guru sebagai pendamping peneliti untuk melaksanakannya.

Kedua, pemahaman guru yang kurang dalam mengajari materi pembelajaran bahasa Jerman dengan menerapkan langkah-langkah pada strategi kelompok.

Ketiga, dalam menentukan kelompok pada kelas dengan perlakuan strategi kelompok, guru tidak memperhatikan karakteristik siswa dalam hal motivasi, sehingga di dalam kelompok terdapat hanya siswa yang bermotivasi tinggi saja saja dan sebaliknya hanya siswa yang bermotivasi rendah saja.

Keempat, penelitian ini hanya dilakukan terhadap satu kelas pada pembelajaran kelompok dan satu kelas pada pembelajaran strategi pembelajaran individu, sehingga penelitian ini belum dapat digeneralisasikan ke dalam ruang lingkup yang lebih luas, kecuali apabila karakteristik siswa dan materinya pelajaranya sesuai dengan karakteristik penelitian ini.

\section{PENUTUP}

Simpulan-simpulan yang dapat ditarik dari hasil pengujian hipotesis adalah sebagai berikut:

Pertama, terdapat perbedaan rata-rata kemampuan membaca bahasa Jerman siswa yang dibelajarkan dengan strategi pembelajaran kelompok secara keseluruhan baik pada kelompok siswa dengan motivasi belajar tinggi maupun motivasi belajar rendah dengan ratarata kemampuan membaca siswa yang dibelajarkan dengan strategi pembelajaran individu. Dengan demikian strategi kelompok lebih efektif diterapkan dalam pembelajaran bahasa Jerman guna meningkatkan hasil belajar siswa tanpa memperhatikan adanya perbedaan motivasi belajar.

Kedua, rata-rata kemampuan membaca siswa dengan motivasi belajar tinggi secara keseluruhan baik yang dibelajarkan dengan strategi kelompok maupun strategi individu lebih tinggi dibandingkan dengan kemampuan membaca siswa dengan motivasi belajar rendah.

Ketiga, hasil perhitungan analisis varians menunjukkan bahwa terdapat interaksi antara strategi pembelajaran dengan motivasi belajar, yang rata-rata kemampuan membaca siswa dengan motivasi belajar tinggi lebih baik menggunakan strategi pembelajarankelompok, rata-rata kemampuan membaca siswa dengan motivasi belajar rendah lebih baik menggunakan strategi kelompok dibandingkan dengan strategi individu.

\section{DAFTAR PUSTAKA}

Anderson, O.W. dan Krathwohl, D.R. 2001. Taxonomy for Learning, Teaching, and Assessing. New York: Addison Wesley Longman, Inc. 
Arends, R. 2008. Learning To Teach. Yogjakarta: Pustaka Pelajar.

Ary, D. Jacobs, L.C Razavieh, A. (1982). Pengantar Penelitian Dalam Pendidikan. (Penerjemah Furcham, A). Surabaya : Usaha Nasional.

Bobbi DePorter, Dkk .2007. Quantum Teaching. Bandung : Penerbit Kaifa.

Djamarah, Saiful.2006.Strategi Belajar Mengajar.Jakarta : Rineka Cipta.

Dahar, Ratna Wilis. 1989. Teori-Teori Belajar. Bandung : PT. Gelora Aksara Pratama.

Dick, W. \& Carey, L. 2005. The Systematic Design of Instruction. Glenview, Illinois: Scoot, Foresman and Company.

Frick, Heinz. 2003. Ilmu Konstruksi Stuktur Bangunan. Yogyakarta : Kanisius

Gagne, R. M. 1977. The Condition of Learning. New York: Halt Rinerhart and Winston.

Gerlach and Elly. 1980. Teaching and Media Asystematic Approach. Englewood Cliffs, N.J.

Gunawan A.W. 2007. Born to be A Genius. Jakarta: Gramedia Pustaka.

Hernowo. 2004. Vitamin $T$ : Bagaimana Mengubah Diri Lewat Membaca dan Menulis. Bandung : Mizan Learning Center.

2005. Quantum Reading : Cara Cepat nan Bermanfaat Untuk Merangsang Munculnya Potensi Membaca. Bandung : Mizan Learning Center.

Lassei. 1986. The Great of Brain. New York: Macmillan Company.

Lazzader. 2003. Menggambar Teknik Dasar. Jakarta: PT. Gramedia

Munandar, Utami. 1998. Memupuk Bakat dan Kreativitas Siswa Sekolah Menengah. Jakarta: PT. Gramedia

Nasoetion, N. dan Suryanto. A. Tes, Pengukuran, dan Penilaian. Jakarta: Pusat Penerbitan UT. 2002.

Nasution, S. 2005. Berbagai Pendekatan Dalam Proses Belajar dan Mengajar. Jakarta : Bumi Aksara.

Nurhadi. 2003. Contextual Teaching and Learning. Jakarta: Depdikbud Dirjen Dikti.

Prawiradilaga, D.S. 2007. Prinsip Desain Pembelajaran. Jakarta : Kencana

Rakhmat, Jalaluddin. 2006. Belajar Cerdas. Bandung : Mizan Learning Center.

Sanjaya, Wina. 2009. Strategi Pembelajaran Berorientasi Standar Proses Pendidikan. Jakarta : Kencana Prenada Media Group
Shindunata. 2000. Mengagas Paradigma Baru Pendidikan. Jakarta : Kanisius.

Soemanty, Wasty, 1984, Psikologi Pendidikan. Jakarta: Bina Aksara

Seels, B.B \& Richey. 1994. Instructional Technology: The Defenition and Domain of Field. Washington, DC : AECT.

Suryosubroto, B. 2009. Proses Belajar Mengajar Disekolah. Jakarta : Rineka Cipta.

Snelbecker, G. 1974. Learning Theory, Instructiona Theory, and Psychoeducational Design. New York: McGraw-Hill Book Company.

Tan, O.S. 2004. Students' experiences in problem-based learning: Three Blind Innovations in Education and Teaching International. Singapore: Thomson Learning.

Uno, H. 2008. Perencanaan Pembelajaran. Jakarta: Bumi Aksara.

Winkel, W. S. 2007. Psikologi Pengajaran. Yogyakarta: Media Abadi.

Wena,M. 2009. Strategi Pembelajaran Inovatif Kontemporer. Jakarta: Bumi Aksara.

Windura, Sutanto. 2008. Mind Map Langkah Demi Langkah. Jakarta : Elex Media Komputindo 